\title{
COMPARISON OF LONG TERM ORAL SUPPLEMENTATION WITH TWO DOSAGES OF CHOLECALCIFEROL ON SERUM 25 - HYDROXYVITAMIN D IN PATIENTS WITH POSTMENOPAUSAL OSTEOPOROSIS
}

\author{
DANIEL GRIGORIE ${ }^{1,2 *}$, ANDRA CARAGHEORGHEOPOL ${ }^{1}$, DIANA COLEȘ ${ }^{1}$, ALINA \\ ȘUCALIUC ${ }^{1}$ \\ I' "C. I. Parhon” National Institute of Endocrinology, Bucharest, Romania \\ 2 "Carol Davila" University of Medicine and Pharmacy, Bucharest, Romania \\ *corresponding author: grigoriedd@yahoo.com
}

Manuscript received: January 2019

\begin{abstract}
This study reports on the efficacy of two different daily oral doses of cholecalciferol supplementation (high dose group 1000 $\mathrm{IU} /$ day and low dose group $500 \mathrm{IU} /$ day) for one year to 100 patients with postmenopausal osteoporosis (PMO) to achieve serum concentration of 25- hydroxyvitamin D (25OHD) of $20 \mathrm{ng} / \mathrm{mL}$ and $30 \mathrm{ng} / \mathrm{mL}$. Two thirds of the whole study group $(66 \%)$ had values below $20 \mathrm{ng} / \mathrm{mL}$ and $90 \%$ had $<30 \mathrm{ng} / \mathrm{mL}$ at baseline. After one year of supplementation, in the high dose group none was deficient, $85.1 \%$ had values above $20 \mathrm{ng} / \mathrm{mL}$, half had $\geq 30 \mathrm{ng} / \mathrm{mL}$ and the mean serum $25 \mathrm{OHD}$ increased from 17.9 to $29.2 \mathrm{ng} / \mathrm{mL}(\mathrm{p}<<0.0001$ ). In the low dose group, $4 \%$ of the patients were still deficient, $65.2 \%$ had values above $20 \mathrm{ng} / \mathrm{mL}, 19 \%$ above $30 \mathrm{ng} / \mathrm{mL}$ and $25 \mathrm{OHD}$ increased from 19.3 to $23 \mathrm{ng} / \mathrm{mL}$ (p = 0.06). Oral cholecalciferol supplementation for one year with $1000 \mathrm{IU} /$ day is adequate to achieve serum $25 \mathrm{OHD}$ concentrations higher than $20 \mathrm{ng} / \mathrm{mL}$ for most of the patients. If the target concentration was $30 \mathrm{ng} / \mathrm{mL}$, the treatment is successful only for half of the patients. No vitamin D deficiency was recorded for patients under this dosage after one year.
\end{abstract}

\section{Rezumat}

Acest studiu raportează eficacitatea suplimentării orale cu două doze diferite de colecalciferol (1000 UI şi 500 UI) timp de un an la 100 de paciente cu osteoporoză de postmenopauză cu scopul de a atinge concentrații serice ale $25 \mathrm{OHD} \mathrm{de} 20 \mathrm{ng} / \mathrm{mL} s ̧ i$ $30 \mathrm{ng} / \mathrm{mL}$. Două treimi din grupul studiat (66\%) au avut valori serice ale $25 \mathrm{OHD}$ sub $20 \mathrm{ng} / \mathrm{mL}$ şi 90\% au avut valori sub 30 $\mathrm{ng} / \mathrm{mL}$. După un an de suplimentare în grupul cu doză mare niciun pacient nu a fost deficitar, $85,1 \%$ au avut valori peste 20 $\mathrm{ng} / \mathrm{mL}$, jumătate având valori $\geq 30 \mathrm{ng} / \mathrm{mL}$, cu o creștere medie a $25 \mathrm{OHD}$ serice de la 17,9 ng/mL la $29,2 \mathrm{ng} / \mathrm{mL}$ (p $<<$ 0,0001). În grupul cu doză mică $4 \%$ dintre pacienți aveau încă deficit, $65,2 \%$ au avut valori peste $20 \mathrm{ng} / \mathrm{mL}$ și $19 \%$ valori peste $30 \mathrm{ng} / \mathrm{mL}$, cu o creștere medie a 25OHD serice de la $19,3 \mathrm{ng} / \mathrm{mL}$ la $23 \mathrm{ng} / \mathrm{mL}(\mathrm{p}=0,06)$. Suplimentarea orală zilnică timp de un an cu 1000 UI colecalciferol este adecvată în majoritatea cazurilor pentru atingerea concentrațiilor serice de $25 \mathrm{OHD}>20 \mathrm{ng} / \mathrm{mL}$, iar $50 \%$ ating concentrații serice $>30 \mathrm{ng} / \mathrm{mL}$.

Keywords: vitamin D supplementation, vitamin D deficiency, postmenopausal osteoporosis

\section{Introduction}

Vitamin D, a threshold nutrient, is essential for bone health and the nutritional status of an individual is currently assessed by measuring the serum concentration of 25-hydroxyvitamin D (25OHD). The state-of-theart method to measure 25OHD is LC-MS/MS (liquid chromatography-tandem mass spectrometry), although automated immunoassays that measure only total serum 25-hydroxyvitamin D are still routinely used in many clinical facilities [1-3].

Vitamin D deficiency and insufficiency are quite prevalent in osteoporotic patients and when prolonged and severe causes secondary hyperparathyroidism, bone loss, maybe inadequate response to antiosteoporotic treatment, muscle weakness and increased risk of falls and fractures [4-10].
The lack of serum 25OHD assays standardization, variability of reference population and the use of different cut-off points have produced quite different prevalence reports from epidemiological studies [1115]. Most clinicians agree that a serum $25 \mathrm{OHD}<10$ $\mathrm{ng} / \mathrm{mL}$ represents severe vitamin D deficiency [16, 17], although osteomalacia was not always found on histology studies. Other experts favour for deficiency thresholds $<12 \mathrm{ng} / \mathrm{mL},<15 \mathrm{ng} / \mathrm{mL}$ or less than 20 $\mathrm{ng} / \mathrm{mL}$, but most data came from populations where the food is fortified with vitamin D and the supplementation is more frequent $[14,16,18]$. As a consequence, many guidelines recommend target serum 25OHD of $\geq 20 \mathrm{ng} / \mathrm{mL}[16,17,19,20]$. The Endocrine Society (US) favours an optimal concentration of at least 30 $\mathrm{ng} / \mathrm{mL}$ and suggests doses as high as $1500-2000 \mathrm{IU}$ 
[21]. The oral dose of cholecalciferol required to achieve and maintain an adequate 25OHD status is controversial and many experts consider high doses to achieve extraskeletal benefits also [22].

This study aimed to compare the efficacy of two different daily oral doses of cholecalciferol (1000 IU vs. $500 \mathrm{IU})$ to achieve serum concentrations of $25 \mathrm{OHD}$ above either $20 \mathrm{ng} / \mathrm{mL}$ or $30 \mathrm{ng} / \mathrm{mL}$, the most relevant thresholds identified in most of the studies.

\section{Materials and Methods}

Design and study group. This was a retrospective observational study conducted in an osteoporosis referral centre. One hundred postmenopausal women with osteoporosis (diagnosed using WHO criteria by dual-energy X-ray absorptiometry, DXA) with no recent history of vitamin D supplementation were selected from our database at the National Institute of Endocrinology, Bucharest, Romania. All patients received antiosteoporotic medication (antiresorptive) and supplementation with cholecalciferol for at least one year with a level of compliance over $80 \%$. The type of oral supplement (pills, solution, with or without calcium) was the physician/patient decision. Secondary causes of osteoporosis were excluded as well as any other disorder or medications influencing bone and mineral metabolism.

The evaluation included demographic data and determination of serum concentrations of 25OHD, PTH, calcium, phosphorus, alkaline phosphatase, creatinine and urinary calcium at baseline and after one year of supplementation with cholecalciferol. Baseline characteristics of the 100 patients with postmenopausal osteoporosis are listed in Table I.

The patients were subgrouped according to the oral dose of cholecalciferol used in: high dose group $1000 \mathrm{IU} /$ day (74 patients) and low dose group 500 IU/day (26 patients). Different cut-offs of serum 25OHD concentrations were analysed at baseline and after repletion: $<10 \mathrm{ng} / \mathrm{mL}, 10-20 \mathrm{ng} / \mathrm{mL}, 20-30$ $\mathrm{ng} / \mathrm{mL}, \geq 30 \mathrm{ng} / \mathrm{mL}$ and we used the Endocrine Society definitions of deficiency $<10 \mathrm{ng} / \mathrm{mL}$, insufficiency $10-30 \mathrm{ng} / \mathrm{mL}$ and sufficiency $\geq 30 \mathrm{ng} / \mathrm{mL}$ [21].

Our primary objective is to report the efficacy of different daily oral doses of cholecalciferol supplementation used over one year in patients with postmenopausal osteoporosis in order to achieve serum concentrations of $25 \mathrm{OHD}$ of $20 \mathrm{ng} / \mathrm{mL}$ and $30 \mathrm{ng} / \mathrm{mL}$. Secondly, to analyse the vitamin $\mathrm{D}$ status at baseline and to observe the change of vitamin D status over supplementation and to make recommendations about monitoring of 25OHD concentrations.

The serum concentration of $25 O H D$ was measured using an ELISA method (ImmunDiagnostic 25OHD
EIA-kit) with an intra-assay and inter-assay $\mathrm{CV}<10 \%$, minimum detection limit of $1.4 \mathrm{ng} / \mathrm{mL}$; normal range: $19-58 \mathrm{ng} / \mathrm{mL}$. The measurements covered all seasons equally. Serum intact PTH was measured by ELISA (DSL-10-8000 ACTIVE I-PTH), intra-assay and interassay $\mathrm{CV}<6.3 \%$, minimum detection limit of $1 \mathrm{pg} / \mathrm{mL}$; normal range: $16-62 \mathrm{pg} / \mathrm{mL}$. The biochemistry parameters (serum calcium, phosphate, alkaline phosphatase and creatinine) were assessed by an automated analyser.

Areal bone mineral density (BMD) was measured by DXA at the lumbar spine, L1 - L4 (LS) and femoral neck (FN) (GE-Lunar Prodigy).

The informed consent for collection of data was obtained from all patients.

Statistical analysis. The results are expressed as mean \pm SD. The comparison of continuous variables was performed using Student's t-test or Mann-Whitney $\mathrm{U}$ test as appropriate, after checking for assumption for distribution normality (Shapiro-Wilk test) and equality of variances (Levene's test). $\mathrm{P}$ values of $<0.05$ were considered significant.

\section{Results and Discussion}

Our study group consisted in 100 postmenopausal women with osteoporosis, mean age $63.1 \pm 9.2$ years, mean BMI $25.1 \pm 4.1 \mathrm{~kg} / \mathrm{m}^{2}$, and baseline biochemical findings are listed in Table I.

Table I

Baseline laboratory characteristics

\begin{tabular}{lc}
\hline \multicolumn{1}{c}{ Characteristic } & Mean \pm SD \\
\hline Serum 25OHD $(19.8-58 \mathrm{ng} / \mathrm{mL})$ & $18.3 \pm 7.8$ \\
Serum PTH $(16-62 \mathrm{pg} / \mathrm{mL})$ & $79.2 \pm 43.5$ \\
Serum calcium $(8.5-10.4 \mathrm{mg} / \mathrm{dL})$ & $9.5 \pm 0.4$ \\
Serum phosphorus $(2.5-4.5 \mathrm{mg} / \mathrm{dL})$ & $3.4 \pm 0.4$ \\
Alkaline phosphatase $(35-110 \mathrm{U} / \mathrm{L})$ & $82.9 \pm 44.6$ \\
Serum creatinine $(0.5-1.1 \mathrm{mg} / \mathrm{dL})$ & $0.7 \pm 0.1$ \\
Urinary Ca $(0.07-0.3 \mathrm{~g} / 24 \mathrm{~h})$ & $0.2 \pm 0.1$ \\
\hline
\end{tabular}

Patient distribution in the four 25OHD categories at baseline was: $12 \%$ in $<10 \mathrm{ng} / \mathrm{mL}, 54 \%$ in $10-20$ $\mathrm{ng} / \mathrm{mL}, 24 \%$ in $20-30 \mathrm{ng} / \mathrm{mL}$ and $10 \%$ in $\geq 30$ $\mathrm{ng} / \mathrm{mL} .66 \%$ of the patients had baseline serum $25 \mathrm{OHD}$ values $<20 \mathrm{ng} / \mathrm{mL}$ and $90 \%<30 \mathrm{ng} / \mathrm{mL}$.

After one year of vitamin D supplementation, in the high dose group, the mean serum 25OHD was 29.3 $\mathrm{ng} / \mathrm{mL}$ and the patient distribution was: zero patients in $<10 \mathrm{ng} / \mathrm{mL}, 14.9 \%$ in $10-20 \mathrm{ng} / \mathrm{mL}, 35.1 \%$ in $20-30 \mathrm{ng} / \mathrm{mL}$ and $50 \%$ in $\geq 30 \mathrm{ng} / \mathrm{mL}$; therefore, $85.1 \%$ of the patients achieved concentrations above $20 \mathrm{ng} / \mathrm{mL}$. In the low dose group, the mean serum $25 \mathrm{OHD}$ was $23 \mathrm{ng} / \mathrm{mL}$ and patient distribution was: $4 \%$ in $<10 \mathrm{ng} / \mathrm{mL}, 30.8 \%$ in $10-20 \mathrm{ng} / \mathrm{mL}, 46.2 \%$ in $20-30 \mathrm{ng} / \mathrm{mL}$ and $19 \%$ in $\geq 30 \mathrm{ng} / \mathrm{mL} .65 .2 \%$ have reached values over $20 \mathrm{ng} / \mathrm{mL}$. We summarized these data in Table II. 
Table II

Patient distribution in categories of serum 25OHD at baseline and after supplementation for 1 year with both

\begin{tabular}{|c|c|c|c|c|c|c|}
\hline \multirow[t]{2}{*}{ Vitamin D groups } & \multicolumn{2}{|c|}{ Baseline } & \multicolumn{4}{|c|}{ At 1 year } \\
\hline & $\begin{array}{c}\% \\
\mathrm{~N}=100\end{array}$ & Mean (ng/mL) & $\begin{array}{c}\% \text { high dose } \\
N=74\end{array}$ & Mean (ng/mL) & $\begin{array}{c}\% \text { low dose } \\
N=26\end{array}$ & Mean $(\mathrm{ng} / \mathrm{mL})$ \\
\hline $\begin{array}{l}<10 \mathrm{ng} / \mathrm{mL} \\
<20 \mathrm{ng} / \mathrm{mL} \\
>20 \mathrm{ng} / \mathrm{mL} \\
>30 \mathrm{ng} / \mathrm{mL}\end{array}$ & $\begin{array}{l}12 \\
66 \\
34 \\
10\end{array}$ & $\begin{array}{l}7.97 \\
11.6 \\
29.0 \\
35.3\end{array}$ & $\begin{array}{c}0 \\
14.9 \\
85.1 \\
50\end{array}$ & $\begin{array}{c}- \\
15.5 \\
30.6 \\
36.7\end{array}$ & $\begin{array}{c}4 \\
34.8 \\
65.2 \\
19\end{array}$ & $\begin{array}{c}9.8 \\
12.7 \\
30.1 \\
35.8\end{array}$ \\
\hline
\end{tabular}

Mean serum baseline 25OHD in the high and low dose groups were $17.9 \mathrm{ng} / \mathrm{mL}$ and $19.3 \mathrm{ng} / \mathrm{mL}$ respectively $(\mathrm{p}=\mathrm{NS})$. After one year of supplementation, serum $25 \mathrm{OHD}$ significantly increased to a mean of 29.3 $\mathrm{ng} / \mathrm{mL}$ in high dose group ( $\mathrm{p}<<0.0001$ vs. baseline) and to a mean of $23 \mathrm{ng} / \mathrm{mL}$ in low dose group $(\mathrm{p}=0.06 v s$. baseline); the difference between the achieved concentrations in the high and low dose groups was highly significant $(\mathrm{p}=0.001)$. The absolute increase in serum $25 \mathrm{OHD}$ at one year for both groups was: a mean of $11.28 \mathrm{ng} / \mathrm{mL}$ for the high dose group and of $3.72 \mathrm{ng} / \mathrm{mL}$ for the low dose group. This suggests a dose dependent increase of $0.5 \mathrm{ng} / \mathrm{mL}$ for every $1 \mu \mathrm{g}$ of cholecalciferol (Figure 1).

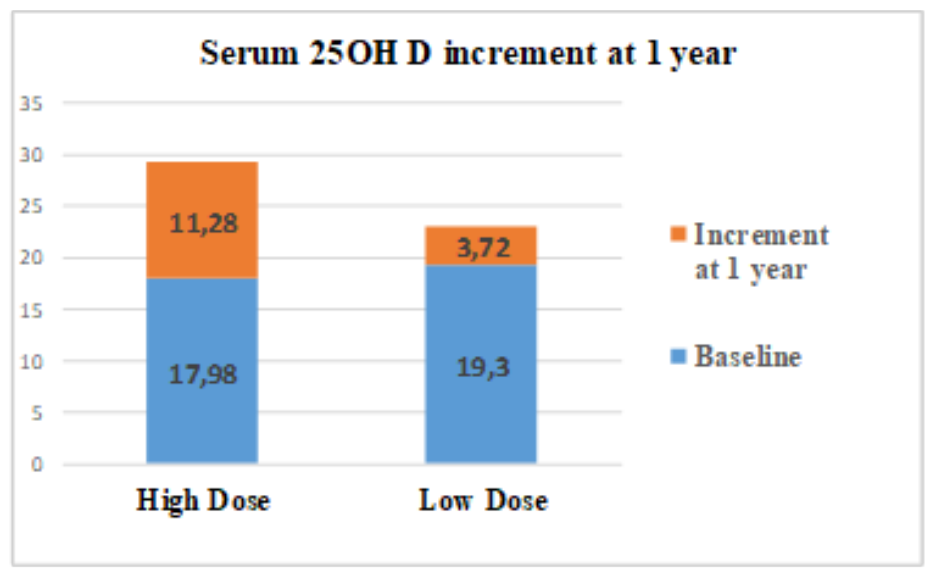

Figure 1.

The absolute increase in serum $25 \mathrm{OHD}(\mathrm{ng} / \mathrm{mL})$ at 1 year for both groups

The correlation between serum 25OHD before supplementation and the absolute and relative increase after one year of supplementation in high dose group, shows that the increase in $25 \mathrm{OHD}$ was inversely related to its initial concentration $(\mathrm{r}=-0.780)$ (Figure 2).

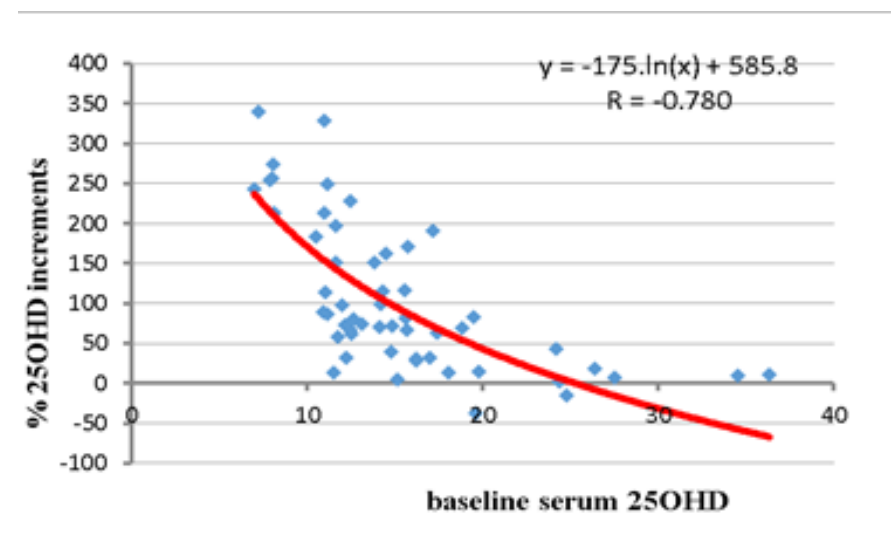

Figure 2.

Correlation between serum $25 \mathrm{OHD}(\mathrm{ng} / \mathrm{mL})$ before supplementation and the relative increase after 1 year of supplementation 
FARMACIA, 2019, Vol. 67, 5

After one year of supplementation we found a significant decrease in serum PTH (mean PTH 54.2 $\mathrm{pg} / \mathrm{mL}, \mathrm{p}=0.001)$ and serum alkaline phosphatase (mean $60.5 \mathrm{mg} / \mathrm{dL}, \mathrm{p}<<0.0001$ ) in the high dose group. No differences were observed in serum calcium and phosphorus compared with baseline $(\mathrm{p}=\mathrm{NS})$ (data not shown).

Our study identified the oral daily dose of $1000 \mathrm{IU}$ of cholecalciferol adequate for supplementation in patients with postmenopausal osteoporosis (PMO), as $85 \%$ of the patients achieved concentrations above $20 \mathrm{ng} / \mathrm{mL}$, believed to prevent bone loss. A lower dose is not effective in all patients to prevent very low concentrations (severe deficiency). Both observations confirm previous data and recommendations [16, 17, 19]. This is an important issue as the clinical phenotype of severe deficiency is osteomalacia in adults. The 1000 IU dose is also recommended by almost all guidelines [16, 17] including the quite recently released European and Endocrine Society (US) guidelines for post-menopausal osteoporosis $[23,24]$.

In Romania, as elsewhere [25], many practitioners and laboratories use the Endocrine Society vitamin D categories. As a consequence, many physicians recommend oral doses as high as 2000 to $4000 \mathrm{IU}$ daily to achieve the $30 \mathrm{ng} / \mathrm{mL}$ concentration.

This is in spite of quite recent data from systematic reviews and meta-analyses which are rather negative for higher doses of supplementation (more than 2000 $4000 \mathrm{IU})$ and even observing no effect on bone density, fractures and falls in subjects without severe deficiency or above a threshold of $12 \mathrm{ng} / \mathrm{mL}$ [2631]. These negative results were criticised as they included very few patients with severe vitamin D deficiency, as are the western populations [32]. In addition, the Institute of Medicine (US) report conclude that there is no additional benefit of achieving serum $25 \mathrm{OHD}$ of $30 \mathrm{ng} / \mathrm{mL}(75 \mathrm{nmol} / \mathrm{L})$ when compared to $20 \mathrm{ng} / \mathrm{mL}$ (50 nmol/L) [33]. Over and above, Larsson et al. stated in a recent mendelian randomization study no causal association between long-term higher serum 25OHD concentrations and BMD in generally healthy population [34].

High doses of vitamin D for supplementation were encouraged not mainly for musculoskeletal endpoints but by the results of observational studies suggesting extraskeletal benefits (cancer chemoprophylaxis, cardiovascular benefits). The consequences of that is the medicalization of vitamin D measurement and supplementation which is seen today. The awaited results of randomized controlled trials with extraskeletal endpoints are just published and are rather negative $[35,36]$.

The strengths of our study are multiple: it compares high and low dose in the accepted definition, use of multiple 25OHD thresholds, control of patient compliance, long follow-up (precluded influences of the seasonal variation) and Romanian cohort of PMO.

As expected, the increase in serum 25OHD inversely relates to its initial concentration suggesting that achieved increases in serum 25OHD are higher in patients with lower baseline levels, consistent with reports from several studies [37, 38].

As $85 \%$ of the patients achieved concentrations above $20 \mathrm{ng} / \mathrm{mL}$, there is no need for monitoring, except in selected cases. We agree with international organizations like the US Preventive Services Task Force (USPSTF) which found little evidence to support screening/monitoring for vitamin D [39] as patients with osteoporosis receive supplements of vitamin D as part of the therapeutic regimen.

Our present study also observed a high prevalence of low vitamin D levels even when using different cutoffs: $66 \%<20 \mathrm{ng} / \mathrm{mL}$ and $90 \%<30 \mathrm{ng} / \mathrm{mL}$, confirming other reports, including ours [11-15, 40, 41].

Our study has several limitations: the retrospective design and the lack of bone data (BMD, turnover) as patients were on bisphosphonate treatment.

In conclusion, supplementing PMO patients with 1000 IU of vitamin D daily is rational because of the high prevalence of inadequacy and enough to achieve a threshold considered to prevent bone loss. We suggest rechecking only in selected cases.

\section{Conclusions}

Our data support the notion that oral daily supplementation with $1000 \mathrm{IU}$ of cholecalciferol is adequate for almost all the patients with PMO in order to achieve a target concentration of $20 \mathrm{ng} / \mathrm{mL}$. This is consistent with the most recent recommendations from other countries, compelling RCTs, and metaanalyses. For patients who fail to reach or sustain this concentration we suggest rechecking.

\section{Conflict of interest}

No potential conflicts of interest were disclosed.

\section{References}

1. Sempos CT, Betz JM, Camara JE, Carter GD, Cavalier E, Clarke MW, Dowling KG, Durazo-Arvizu RA, Hoofnagle AN, Liu A, Phinney KW, Sarafin K, Wise SA, Coates PM, General steps to standardize the laboratory measurement of serum total 25- hydroxyvitamin D. J AOAC Int., 2017; 100(5): 1230-1233.

2. Giustina A. Robert A. Adler RA, Binkle N, Bouillon R, Ebeling PR, Lazaretti-Castro M, Marcocci C, Rizzoli R, Sempos CT, Bilezikian JP, Controversies in Vitamin D: Summary Statement From an International Conference. J Clin Endocrinol Metab., 2019; 104(2): 234-240.

3. Avenell A, Bolland MJ, Andrew Grey A, 25Hydroxyvitamin D - Should labs be measuring it? Annal Clin Biochem., 2019; 56(2): 188-189. 
4. Bischoff-Ferrari HA, Willett WC, Wong JB, Dietrich T, Dawson-Hughes B, Fracture prevention with vitamin D supplementation: a meta-analysis of randomized controlled trials. JAMA, 2005; 293(18): 2257-2264.

5. Grigorie D, Coles D, Caragheorgheopol A, Şucaliuc A, Vitamin D status and consequences of long term supplementation with oral native vitamin D3 on the severity of primary hyperparathyroidism - The Romanian experience. Farmacia, 2018; 66(5): 877-882.

6. Bilezikian JP, Silverberg SJ, The role of parathyroid hormone and vitamin $\mathrm{D}$ in the pathogenesis of osteoporosis. Marcus and Feldman Osteoporosis, $2^{\text {nd }}$ Ed. 2001; 2: 71-79.

7. Guo Ning, Li Bingliang, Jiang Xiaorui, The efficacy of a phytoestrogen-rich Chinese medicine on senile osteoporosis. Farmacia, 2018; 66(6): 1076-1080.

8. Grigorie D, Sucaliuc A, Ivan M, Neacsu E, Militaru R, Vitamin D status affects 1 year BMD response to ibandronate treatment in patients with postmenopausal osteoporosis. Osteoporos Int., 2010; 21(Suppl1): S191.

9. Mosekilde L, Vitamin D and the elderly. Clinical Endocrinology, 2005; 62: 265-281.

10. Lips P, Vitamin D deficiency and secondary hyperparathyroidism in the elderly: consequences for bone loss and fractures and therapeutic implications. Endocr Rev., 2001; 22(4): 477-501.

11. Bouillon R, Van Schoor NM, Gielen E, Boonen S, Mathieu C, Vanderschueren D, Lips P, Optimal vitamin D status: a critical analysis on the basis of evidence-based medicine. J Clin Endocrinol Metab., 2013; 98(8): E1283-304.

12. Holick MF, High prevalence of vitamin D inadequacy and implications for health. Mayo Clin Proc., 2006; 81(3): 353-373.

13. Holick MF, Siris ES, Binkley N, Beard MK, Khan A, Katzer JT, Petruschke RA, Chen E, Prevalence of Vitamin D inadequacy among postmenopausal North American women receiving osteoporosis therapy. $J$ Clin Endocrinol Metab., 2005; 90(6): 3215-3224.

14. Holick MF, Chen TC. Vitamin D deficiency: a worldwide problem with health consequences. $\mathrm{Am}$ J Clin Nutr., 2008; 87: 1080S-1086S.

15. Cashman KD, Dowling KG, Škrabáková Z, GonzalezGross M, Valtueña J, De Henauw S, Moreno L, Damsgaard CT, Michaelsen KF, Mølgaard C, Vitamin D deficiency in Europe: pandemic?. Am J Clin Nutr., 2016; 103: 1033-1044.

16. Munns CF, Shaw N, Kiely M, Specker BL, Thacher TD, Ozono K, Michigami T, Tiosano D, Mughal MZ, Makitie O, Ramos-Abad L, Ward L, DiMeglio LA, Atapattu N, Cassinelli H, Braegger C, Pettifor JM, Seth A, Idris HW, Bhatia V, Fu J, Goldberg G, Savendahl L, Khadgawat R, Pludowski P, Maddock J, Hypponen E, Oduwole A, Frew E, Aguiar M, Tulchinsky T, Butler G, Hogler W, Global consensus recommendations on prevention and management of nutritional rickets. J Clin Endocrinol Metab., 2016; 101(2): 394-415.

17. Bouillon R, How much vitamin D is needed for healthy bones?. J Intern Med., 2017; 282(5): 461-464.

18. Macdonald HM, Reid IR, Gamble GD, Fraser WD, Tang JC, Wood AD, 25-Hydroxyvitamin D threshold for the effects of vitamin D supplements on bone density: secondary analysis of a randomized controlled trial. J Bone Mineral Res., 2018; 33: 1464-1469.

19. Cashman KD, Ritz C, Kiely M, Odin Collaborators. Improved dietary guidelines for vitamin D: application of individual participant data (IPD)-level meta-regression analyses. Nutrients, 2017; 9(5): 1-17.

20. Compston J, Cooper A, Cooper C, Gittoes N, Gregson C, Harvey N, Hope S, Kanis JA, McCloskey EV, Poole KES, M. Reid DM, Selby P, Thompson F, Thurston A, Vine N, The National Osteoporosis Guideline Group (NOGG), UK clinical guideline for the prevention and treatment of osteoporosis. Arch Osteoporos., 2017; 12(1): 1-24.

21. Holick MF, Binkley NC, Bischoff-Ferrari HA, Gordon CM, Hanley DA, Heaney RP, Murad MH, Weaver CM, Endocrine Society, evaluation, treatment, and prevention of vitamin D deficiency: An Endocrine Society clinical practice guideline. J Clin Endocrinol Metab., 2011; 96(7): 1911-1930.

22. Bischoff-Ferrari HA, Giovannucci E, Willett WC, Dietrich T, Dawson-Hughes B, Estimation of optimal serum concentrations of 25-hydroxyvitamin $\mathrm{D}$ for multiple health outcomes. Am J Clin Nutr., 2006; 84(1): 18-28.

23. Eastell R, Rosen CJ, Black DM, Cheung AM, Murad MH, Shoback D, Pharmacological Management of Osteoporosis in Postmenopausal Women: An Endocrine Society*Clinical Practice Guideline. JCEM, 2019; 104(5): 1-28

24. Kanis JA, Cooper C, Rizzoli R, Reginster JY, European guidance for the diagnosis and management of osteoporosis in postmenopausal women. Osteoporosis International., 2019; 30: 3-44.

25. Rooney MR, Harnack L, Michos ED, Ogilvie RP, Sempos CT, Lutsey PL, Trends in Use of HighDose Vitamin D Supplements Exceeding 1000 or 4000 International Units Daily, 1999-2014. J Am Med Assoc., 2017; 317: 2448-2450.

26. Bolland MJ, Grey A, Avenell A, Effects of vitamin D supplementation on musculoskeletal health: a systematic review, meta-analysis, and trial sequential analysis. Lancet Diabetes and Endocrinology, 2018; 6: 847-858.

27. Bischoff-Ferrari HA, Dawson-Hughes B, Orav EJ, Staehelin HB, Meyer OW, Theiler R, Dick W, Willett WC, Egli A, Monthly High-Dose Vitamin D Treatment for the Prevention of Functional Decline. A Randomized Clinical Trial. JAMA Intern Med., 2016; 176(2): 175-183.

28. Smith LM, Gallagher JC, Suiter C, Medium doses of daily vitamin $\mathrm{D}$ decrease falls and higher doses of daily vitamin D3 increase falls: A randomized clinical trial. J Steroid Biochem Mol Biol., 2017; 173(1): 317-322.

29. Grigorie D, Şucaliuc A, Prevention of falls and fractures - to „D” or not to „D”?. Acta Endocrinologica (Buc), 2018; XIV(2): 235-237.

30. Tricco AC, Thomas SM, Veroniki AA, Hamid JS, Cogo E, Strifler L, Khan PA, Robson R, Sibley KM, MacDonald H, Riva JJ, Thavorn K, Wilson C, Holroyd-Leduc J, Kerr GD, Feldman F, Majumdar SR, Jaglal SB, Hui W, Straus SE, Comparisons of interventions for preventing falls in older adults: a 
systematic review and meta-analysis. JAMA, 2017; 318(17): 1687-1699.

31. Janelle M, Guirguis-Blake MD, Yvonne L, Michael ScD SM, Leslie A, Perdue MPH, Erin L, Coppola MPH, Tracy L, Beil MS, Interventions to Prevent Falls in Older Adults Updated Evidence Report and Systematic Review for the US Preventive Services Task Force. JAMA, 2018; 319(16): 1705-1716.

32. Bischoff-Ferrari HA, Bhasin S, Manson JE, Preventing Fractures and Falls. A Limited Role for Calcium and Vitamin D Supplements?. JAMA, 2018; 319(15): 1552-1553.

33. Rosen CJ, Abrams SA, Aloia JF, Brannon PM, Clinton SK, Durazo Arvizu RA, Gallagher JC, Gallo RL, Jones G, Kovacs CS, IOM committee members respond to Endocrine Society vitamin $\mathrm{D}$ guideline. J Clin Endocrin Metab., 2012; 97: 1146-1152.

34. Larsson SC, Melhus H, Michaëlsson K, Circulating serum 25-Hydroxyvitamin D levels and bone mineral density: Mendelian randomization study. $J$ Bone Miner Res., 2018; 33(5): 840-844.

35. Manson JE, Cook NR, Lee IM, Christen W, Bassuk SS, Mora S, Gibson H, Gordon D, Copeland T, D'Agostino D, Friedenberg G, Ridge C, Vitamin D Supplements and Prevention of Cancer and Cardiovascular Disease. $N$ Engl J Med., 2019; 380: 33-44.

36. Urashima $\mathrm{M}$, Odhaira $\mathrm{H}$, Akutsu K. Effect of vitamin D supplementation on relapse-free survival among patients with digestive tract cancer. The AMATERASU randomized clinical trial. JAMA, 2019; 321(14): 1361-1369.

37. Scientific Advisory Committee on Nutrition. Report on vitamin D and health. London, UK: SACN \& Public Health England, 2016, (www.gov.uk).

38. Pilz S, Zittermann A, Trummer C, Theiler-Schwetz V, Lerchbaum E, Martin H, Keppel MH, Grübler MR, März WS, Pandis M, Vitamin D testing and treatment: a narrative review of current evidence. Endocrine Connections, 2019; 8: R27-R43.

39. LeBlanc E, Chou R, Zakher B, Daeges M, Pappas M, Chou R, Screening for vitamin D deficiency: systematic review for the US preventive services task force recommendation. Ann Intern Med., 2015; 162(2): 109-122.

40. Grigorie D, Sucaliuc A, Ivan M, Neacsu E, Popa O, Diaconescu A, High prevalence of vitamin D deficiency in 1048 Romanian postmenopausal women with osteoporosis. Acta Endocrinologica (Bucharest), 2008; IV: 33-45.

41. Grigorie D, Sucaliuc A, Coles D, Ivan M, Effects of one year high vs low dose oral vitamin D3 supplementation on the vitamin D status in 100 patients with postmenopausal osteoporosis. Bone, 2011; 48(Supp1 2): S213-S235. 